\title{
Geographical Information System (GIS) as a Tool in Surveillance and Monitoring of Animal Diseases
}

\author{
By Madelaine Norstrøm \\ Ullevålsvn. 68, P.B 8156 Dep., N-0033 Oslo, Norge.
}

\begin{abstract}
In the veterinary epidemiology, the advantage of mapping the locations of farms and other facilities with animals is obvious. In an outbreak of a disease it could make the management of the situation easier, and it could also provide a tool to evaluate different strategies to prevent the spread of infectious diseases. This paper aims to describe and give an overview of the possibilities and potential uses of a Geographical Information System (GIS) in the field of surveillance and monitoring of animal diseases. The following areas in which GIS and special GIS-functions could be incorporated are presented: recording and reporting information, epidemic emergency, cluster analysis, modelling disease spread, and planning control strategies. Different sources of data; geographical data, farm locations and disease information, used in the development of the GIS at the National Veterinary Institute in Norway are thoroughly described in the paper. Further, it presents a few examples where the GIS has been applied to studies of epidemiology and surveillance of animal diseases in Norway, which shows the significant value of GIS in these areas. At the same time, the incorporation of GIS in this field shows the scarcity of the data available, which should encourage improvement in the data recording and the quality of the registries.
\end{abstract}

\section{Geographical Information Systems, Surveillance, Epidemiology.}

\section{Introduction}

A Geographical Information System (GIS) can be used as a tool for any discipline which handles with data that can be connected with geographical locations, such as countries, regions, communities, or co-ordinates. The systems have been developing rapidly in the past and today there are a number of different software which are more user-friendly than in the past. GIS is about to become tools for everyone.

The need for using this system also in the field of veterinary medicine has been emerging during the last decade. In 1991 Sanson et al. described the systems and possible applications in the field of veterinary medicine. Still, the most used application of GIS is to produce descriptive maps. However, the potential of GIS is much larger. Reviews in the field of environment and human health (Briggs \& Elliot 1995), and in the field of animal health (Sharma 1994) have been undertaken. GIS has been included in decision support systems for control of infectious diseases in animals (Sanson 1994, Laube 1997).

This paper will attempt to present the technology and possibilities of GIS with regard to surveillance and monitoring of animal diseases, and will discuss some applications of GIS in the field of veterinary epidemiology in Norway.

\section{Geographical information system}

GIS is a computer-based system for analysing and displaying digital geo-referenced data sets (Fig.1).

The data can be stored in two formats; vectorbased and grid-based.

The maps of the vector-based format display 


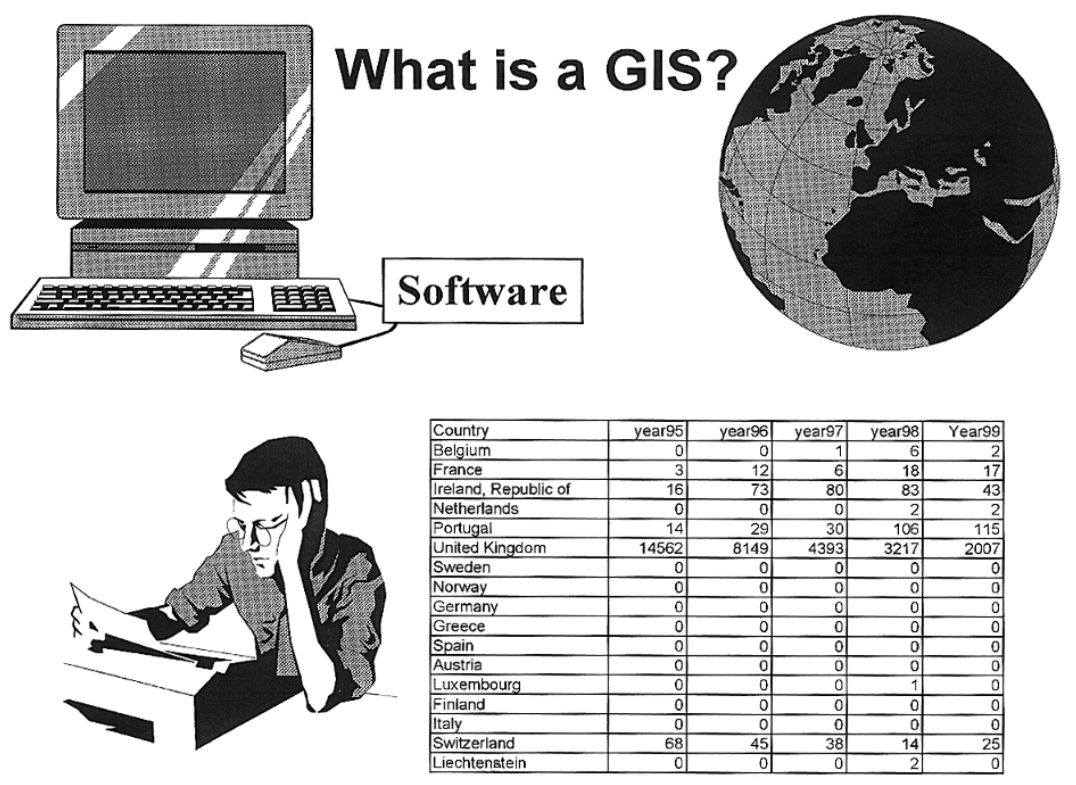

Fig. 1. The structure of a Geographical Information System.

models of the real world using points, lines and polygons. Vector digitising captures a point as a $\mathrm{x}, \mathrm{y}$ co-ordinate, while a line is captured as an ordered string of such co-ordinates. A polygon is a closed line. The grid-based format of data is captured as information of each quadratic cell in a screen and could be looked at as a photo of the area. GIS displays the geo-referenced data as theme layers which can be displayed one at a time or on top of each other, like overheads on a projector. These are stored in a geo-relational database. Each feature has attribute data linked to it which is stored in a table. Attributes can be any item of a feature which relate to the map, without being a part of it. The attribute data of the object with a geographical connection is stored in tables which can be joined with the geographical data through a common identifier (ID). An ID relevant to animal disease data could be a farm or region. Numbers are to prefer as ID as charac- ter variables often can be misspelled. The farms can be visualised using points, and regions such as veterinary districts, municipalities or counties are stored as polygons.

\section{Description of GIS-functions useful in the veterinary surveillance \\ Recording and reporting disease information} GIS can be used to produce maps of disease incidence, prevalence, mortality, morbidity on farm, region, or national levels. The information is more easily understood when visualised on a map. Because information on diseases often tends to be aggregated (from information on each individual herd to municipality or county level) the information loses some of its value. If the information is mapped at the farm level, only small parts of a region can be visualised at the same time.

Another way to describe the incidences of diseases in a defined area can be to create density 
maps by using the density function. The density function creates a grid with a defined cell size and gives each cell in the area a density value of the infected farms. To adjust for the underlying population, a density map of the whole population at risk is created with the same cell size. The density maps are then divided to provide a map that shows the incidence of the particular disease in each area unit at the time unit chosen. This function can further provide maps which show the spread of the disease by displaying the maps as a movie. The GIS can also be incorporated in a real time outbreak notification, as done in an eradication program of the Aujeszky's disease in North Carolina (McGinn et al. 1997). Maps displaying the updated situation in a region, together with farm information are important tools for field personnel and can also be incorporated in reports to producers, administrators and the media.

\section{Epidemic emergency}

In case of an outbreak of an infectious disease, GIS can provide an excellent tool for identifying the location of the case farm and all farms at risk within a specified area of the outbreak. Buffer zones can be drawn around those farms as shown in Fig. 2. and with a link to tables of the addresses of the farms at risk, the farms can be informed within a short time after a notified outbreak. Buffer zones can also be generated around other risk areas or point sources, such as roads where infected cattle have been driven or around market places. Further, the maps can assist the field veterinarians to plan their work in the current situation, and for the veterinary authorities in how to handle a potential outbreak.

\section{Analysis of clustering of diseases}

To analyse whether a disease is clustered in space, time or in time and space other programs

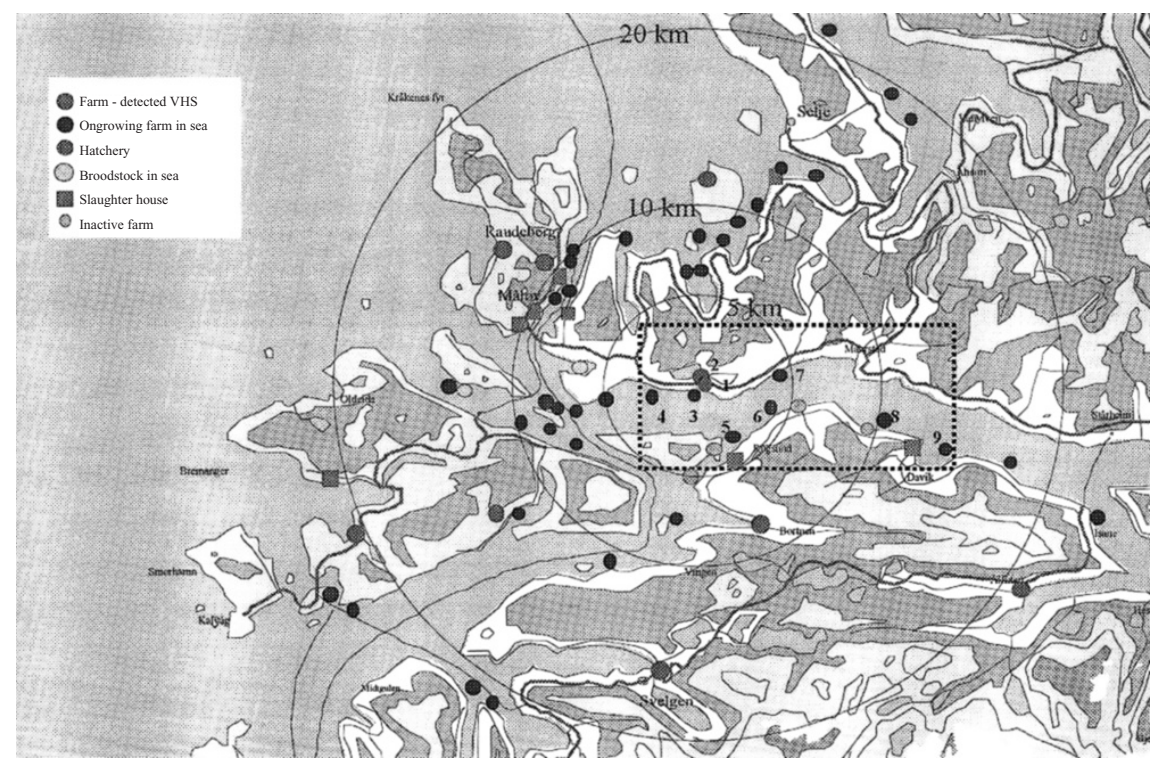

Fig. 2. A map showing an example of how buffer zones with the distance of 5, 10, and 20 kilometres were created around a fish farm with a positive isolation of Viral haemorrhagic septicaemia virus in rainbow trout (1998) to identify nearby locations of different fish farms and slaughterhouses for fish. 
still have to be used because this is not yet a standard tool in the available GIS-packages.

The visualisation of the disease rates on digital maps can be misleading because the eye tends to interpret point patterns as clusters more often than what is real. Therefore, a cluster analysis should be carried out for an objective evaluation of the reported disease cases. The results of some of the cluster analyses can, thereafter, be imported into a GIS to visualise the location of clusters or cluster areas.

\section{Model disease spread}

Simulation models using programmes packages as@Risk (Palisade Corporation, Newfield, NY, USA) can be integrated within a GIS. Such simulation models can incorporate farm information such as herd size, production type as well as spatial factors like distance to the source of outbreak, population density and climate conditions, vegetation and landscape, all of which have been defined as risk factors for the spread of the modelled disease. Sanson, (1994) has developed a model of a potential outbreak of foot and mouth disease in New Zealand.

\section{Planning disease control strategies}

The neighbourhood analysis function can be used to identify all adjacent farms to an infected farm. It is a function that identifies all adjacent features with a certain criteria to a particular feature. Contact patterns such as common use of grasslands or sources of purchasing etc. could be visualised with a so-called spider diagram. This could provide insight into the possibility of transmission of infectious diseases between herds. In the planning of eradication of diseases, GIS has the possibility to perform overlay analysis to find high or low risk areas for diseases which depend on geographical features or conditions related to the geography. Studies of trypanosomiasis (Rogers 1991) and theileriosis (Perry et al. 1991, Lessard et al. 1990), are just some examples of how to use GIS to plan eradication of diseases depending on habitats of vectors or wild animal population. GIS could also be used to find areas with a low density of other farms (Marsh et al. 1991, Staubach et al. 1997, Mc Ginn et al. 1997) or risk areas of diseases as shown by Staubach et al. (1998) in case of Echinococcus multilocularis in foxes.

\section{Description of the sources of the data used in the GIS in the field of veterinary epidemiology in Norway}

Digital maps of Norway are provided and can be purchased from the National Map Department of Norway. The geographic data consisting of themes of each geographical feature are complete for the whole country in the scales 1:1Mill. and 1:250 000. There are maps in the scale 1:50 000 for some parts of Norway.

The administrative boundaries of Norway can be divided into regions such as counties, municipalities, and in the veterinary field, veterinary districts which mostly consist of one ore more municipalities. The themes of veterinary districts were manually created and derived from the themes of the municipalities with the use of ArcView 3.1 (ESRI., Redlands, CA, USA).

The farm locations were provided by the Agriculture Property Registry, which is the official database of all information regarding agriculture in Norway. This registry includes all agricultural properties in the country, including properties with as well as without animal production. Animal producers can be found in the Registry of Production Subsidies (RPS), which records all farms which apply for financial support for their production. This registry is updated twice a year. This registry contains the production number, name, address of the applicant and number of animals in each production 

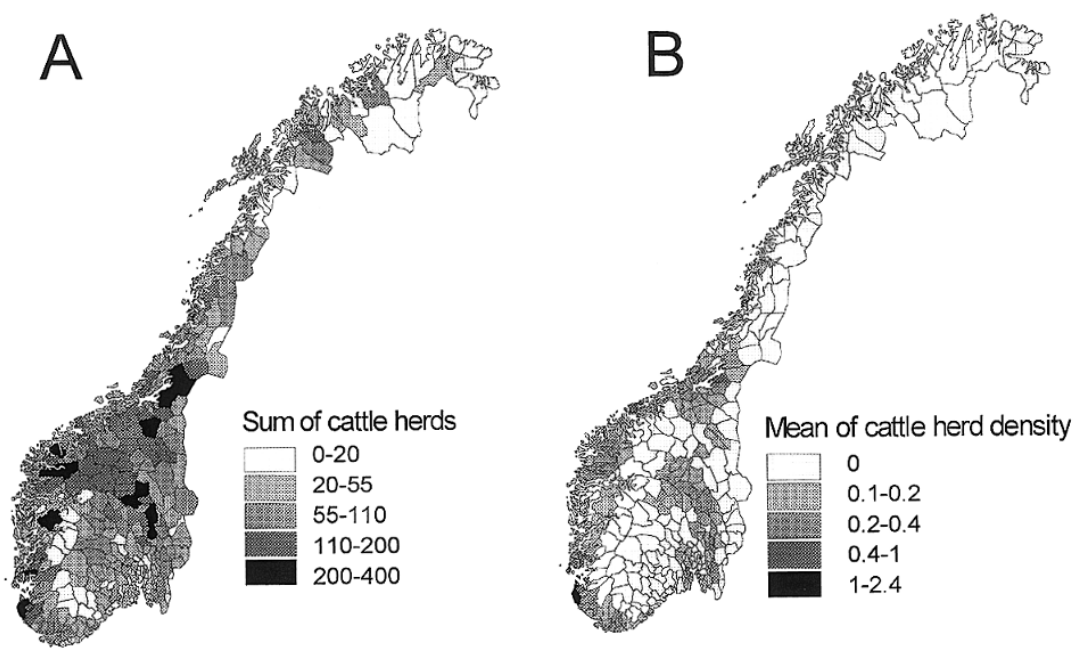

Fig. 3. The map of Norway with the distribution of cattle herds shown as number of herds in each municipality in A) and as number of herds per square kilometre within each municipality in B).

category at the day of application. The information of the locations of the farms with animal production as well as their production type and herd sizes are collected from these two registries. The disease recording system of the National Veterinary Institute includes the results from all tests of samples tested according to surveillance programs as well as diagnostic purposes of disease investigation. Today, all information about disease status in the counties, municipalities or on each farm can be collected from this database and imported into ArcView 3.1 as text files for joining with a geo-referenced theme such as farm, municipality, veterinary district or region. The GIS can thereby show the summarised information at a specific time or over any desired time period. Alternatively, the information in the database can be accessed through the ODBC interface.

A goal of the introduction of GIS is to have maps continuously displaying the situation for each of the diseases included in the Norwegian Surveillance Program.
By the use of the registries described, it has been possible to obtain maps with all registered cattle, swine, sheep, goat and poultry farms in Norway. Density maps of the farms of each production category as well as density maps of the population of each species have also been produced. An example of the maps created for the cattle population in 1998 is shown in Fig. 3. The map to the left shows the number of cattle herds within each municipality and the map to the right shows average number of herds per square kilometres within each municipality. In the following examples of specific projects where GIS has been applied in the field of veterinary epidemiology in Norway. are presented.

\section{Mycoplasma eradication in the swine population}

One of the goals of The Norwegian Pig Health Service is to eradicate Mycoplasma hyopneumoniae from the Norwegian swine population. There are several projects going on and the role of the geographical information system in these 
projects will be to describe and follow the situation over time. The system also provides a tool to plan the eradication of the disease. The swine population in Norway is built up in a breeding pyramid, where the elite herds are at the top, followed by multipliers, conventional herds, and at the bottom of the pyramid; the slaughter pig herds. The strategy of the eradication program is to try to eradicate one level at a time with the starting point at the top. With a GIS the spatial aspects can be included in the eradication program. To avoid re-infection from nearby herds of another level, the program can identify those herds and help in the planning of further eradication of the disease.

\section{Paratuberculosis}

In Norway, Paratuberculosis (PTB) has been considered to be a significant problem in the goat population, whereas PTB in cattle hadn't been diagnosed since 1979. Nevertheless, the fact that Norway claimed to have a PTB free status in the cattle population forced the authorities to start with an active surveillance program to test the cattle population systematically. The surveillance has focused on several risk groups, starting with the imported cattle, thereafter cattle in goat herds with PTB, older cattle, cattle in goat herds and finally a random sample dairy and beef cattle. The GIS has been used to identify the location of all goat herds, goat herds positive for PTB goat herds with cattle. During the test period the GIS has been used to identify the location of sero-positive and bacteriological positive cattle herds and to look for spatial relationship between positive cattle herds and positive goat herds.

\section{An outbreak investigation of bovine respiratory syncytial virus in cattle}

In a study of the transmission of epidemic respiratory disease between cattle herds, data from an outbreak of acute respiratory disease associ- ated with BRSV (Norström et al. submitted) have been used to map the disease occurrence weekly as well as to provide incidence maps, and most likely clusters. The distances between all herds have been calculated by the use of ArcView 3.1 and will be used in a further study of risk factors, involving spatial factors. It is also planned to create a transmission model of acute respiratory disease and apply it in a GIS.

\section{Discussion and conclusions}

A GIS provides significant added value to current routine data that is usually taken into low consideration for either epidemiological or management purposes in veterinary medicine. A GIS considerably increases the efficacy of communication. Management and veterinary service tasks and resources during emergency can be improved with the use of GIS. Description of geographical disease dynamics over time, of risk factors due to spatial relationships as well as the drawing of risk and damage maps become feasible.

The deficiencies in a surveillance system also become more obvious and as a by-product of introduction of GIS, the system of collecting, storing and managing data can be improved. Last but not least, keep in mind: The maps will never be better than the original input data!

\section{References}

Briggs DJ and Elliott P: The use of geographical information systems in studies on environment and health. World Health Statistics quarterly 1995, 48(2): 85-94.

Laube P, Stärk KDC and Keller H: A GIS-based computer program for the region-wide eradication of Enzootic Pneumonia (EP). Proceedings of the 8th International symposium on veterinary epidemiology and economics in Paris in 1997, published in Epidemiologie et sante animale.1997,: 31-32, 12.13.1-12.13.2.

Lessard P, L'Eplattenier RL, Norval RAI, Kundert K, Dolan TT, Croze H, Walker B, Irvin AD and Perry $B D$ : Geographical information systems for 
studying the epidemiology of cattle diseases caused by Theileria parva. Vet. Rec.1990, 126, 255-262.

Marsh WE, Damrongwatanapokin T, Larntz $K$ and Morrison $R B$ : The use of geographic information system in an epidemiological study of pseudorabies (Aujeszky's disease) in Minnesota swine herds. Prev. Vet. Med. 11: 249-254 1991.

McGinn TJ, Cowen P and Wray DW: Intergrating a geographic information system with animal health management. Proceedings of the 8th International symposium on veterinary epidemiology and economics in Paris in 1997, published in Epidemiologie et sante animale. 1997, 31-32: 12. C.36.

Rogers DJ: Satellite imagery tsetse and trypanosomiasis in Africa Prev. Vet. Med. 1991, 11, 201220.

Perry BD, Kruska R, Lessard P, Norval RAI and Kundert $K$ : Estimating the distribution and abundance of Rhipicephalus appendiculatus in Africa. Prev. Vet. Med. 1991, 11, 261-268.

Sanson RL, Ster MW and Morris RS: Interspread-A spatial stochastic simulation model of epidemic foot-and-mouth disease. The Kenyan Veterinarian 1994, 18(2): 493-495.

Sharma P: Use of geographic information systems in animal health information programs. ACIAR Proceedings in 1994 51, 119-125.

Staubach C, Teuffert J and ThulkeH-H: Risk analysis and local spread mechanisms of classical swine Proceedings of the 8th International symposium on veterinary epidemiology and economics in Paris in 1997, published in Epidemiologie et sante animale. 1997, 31-32, 6.12.1-6.12.3.
Staubach C, Tackmann K, Löschner U, Mix H, Busse W, Thulke H-H, Territo BM and Conraths FJ: Geographic information system-aided analysis of factors potentially influencing the spatial distribution of Echinococcus multilocularis infections of foxes. Trushfield MV and Goodall EA, Proceedings of a meeting held at the West County Hotel Ennis CoClare on the 25th 26th and 27th of March 1998: 40-47 1998.

\section{Sammanfattning}

Kartor som visar den geografiska belägenheten av olika djurbesättningar och andra anläggningar med djur är ett gott hjälpmedel inom veterinär epidemiologin. Vid ett utbrott av en smittsam djursjukdom kan det underlätta hanteringen av situationen och också vara ett hjälpmedel för att evaluera olika bekämpningsåtgärder. Denna artikeln har som syfte att beskriva möjliga arbetsområden av geografiska informationssystem (GIS) för övervakning av djursjukdommar. Följande områden inom vilka GIS och speciella GIS funktioner kan användas är presenterade: data insamling och rapportering, epidemisk nödsituation, cluster analys, spridningsmodellering och planering av bekämpningsåtgärder av djursjukdommar. Data källor som; geografiska data, djurbesättningars belägenhet och sjukdoms information har använts i utvecklingen av GIS vid Veterinärinstituttet i Norge och är beskrivna i artikeln. Vidare presenteras ett par exempel på hur GIS har använts i olika epidemiologiska studier samt i övervaknings program. Införandet av GIS visar fort bristerna i de data som är tillgängliga vilket medverkar till förbättring vid insamling av data och kvaliten på registren. 